\title{
PEM Fuel Cells in Applications of Urban Public Transport
}

\author{
I. Zamora ${ }^{1}$, J.I. San Martín ${ }^{2}$, J. García ${ }^{1}$, F.J. Asensio ${ }^{1}$, O. Oñederra ${ }^{1}$, J.J. San Martín², V. Aperribay ${ }^{2}$ \\ Department of Electrical Engineering - University of the Basque Country \\ ${ }^{1}$ Escuela Técnica Superior de Ingeniería de Bilbao \\ ${ }^{2}$ Escuela de Ingeniería de Eibar \\ Alda. Urquijo s/n, 48013 Bilbao (Spain) \\ e_mail: inmaculada.zamora@ehu.es \\ Avda. Otaola, 29, 20600 Eibar (Spain) \\ e_mail: iepsadij@sb.ehu.es
}

\begin{abstract}
This paper is focused on the analysis and design of an electric bus, powered by fuel cell and solar modules. The system uses a $400 \mathrm{~V}$ DC bus, interconnected by electronic converters with photovoltaic modules, batteries, ultracapacitors, fuel cell, electrolyzer, propulsion engines and conditioning devices.

This arrangement allows the energy exchange between devices in an optimal way, allowing also the recovery of braking energy via the inverter, to charge batteries and ultracapacitors, or to generate hydrogen using the electrolyzer.
\end{abstract}

\section{Key words}

Clean Urban Transport, Hydrogen, PEMFC, PV, Ultracapacitors.

\section{Introduction}

Nowadays a new concept in urban public transport gets more and more interest in order to satisfy the energy needs of this sector, with high efficiency, reduced harmful emissions and diversification of fuel use. In this context, fuel cell is a very interesting device. It satisfies the above requirements and adds its quiet operation, modular nature and low maintenance. In recent years, various types of fuel cell buses using different propulsion systems and strategies for energy management have been researched and developed [1-2].

Thus, the Clean Urban Transport for Europe (CUTE) pilot project was carried out by DaimlerChrysler and financed by the European Commission. The project's aim was to demonstrate and evaluate the new technology used by Citaro fuel cell buses, including hydrogen fuel infrastructure. In this project, 27 buses in nine cities (Amsterdam, Barcelona, Hamburg, London, Luxembourg, Madrid, Porto, Stockholm and Stuttgart) were evaluated. In each city, 3 buses were operating in a period of twenty four months. The bus that operated in Madrid, became operational in May 2003. Other buses started its operation in autumn 2003 or early 2004. Cities had different hydrogen supply infrastructures and the buses operated under different conditions, such as: flat or hilly cities, scheduled and unscheduled bus lines, cold and wet or hot and dry climates.
From the analysis of the CUTE project results, it is noteworthy that efficiency, reliability and durability of fuel cells have surprised the institutions that covered the project. Therefore, they decided to extend the experience with the project HyFLEET: CUTE. The project brought together 31 participants, including Iceland, Australia and China [3].

In this paper, aspects related to the design of a fuel cell based bus are presented, covering characteristics of the different components and design criteria.

\section{Clean fuels and propulsion systems for transport}

Since years ago, the EU has been trying to promote the use of biofuels as substitutes for diesel or petrol for transport. As a result, the Directive 2003/30/EC [4] was developed in 2003, to promote the use of biofuels. This Directive requires all EU members to ensure that before December $31^{\text {st }}$, 2010, at least $5.75 \%$ of transport fuels will be biofuels. There are several reasons for promoting the use of biofuels, which include:

1) Reduce the energy dependence of the European Union countries.

2) Stabilize prices of fossil fuels.

3) Reduce emissions of greenhouse gases.

4) Promote demand for agricultural products.

Among the different existing fuel options, the parameter used to compare alternative fuels to gasoline and diesel, is the price per unit of energy, in terms of LHV.

Currently, due to the state of technology development and costs associated with production, the consumption of biofuels is not yet cost-effective [5]. On the other hand, it should be noted that in some European countries, which have a strong primary sector, a high percentage of raw materials used to produce biofuels is imported. This fact calls into question the aim of the European Directive mentioned above, to reduce dependence on foreign energy. So, hydrogen can be an alternative to gasoline, diesel and biofuels for the automotive sector. Depending 
on the energy cost and process efficiency, there are several options which allow that the cost of generating hydrogen by electrolysis could be feasible, without subsidies or tax exemptions.

Regarding the use of hydrogen as an automotive fuel, it can be used in fuel cells. In this case, efficiency in a PEM fuel cell may be around $42 \%$ at nominal power, in terms of LHV [6]. Also, hydrogen can be used in internal combustion engines, but in this case the maximum efficiency in terms of LHV is $27 \%$ [5].

Figure 1 shows the options of using hydrogen as fuel in an electric vehicle, using a fuel cell or an internal combustion engine.
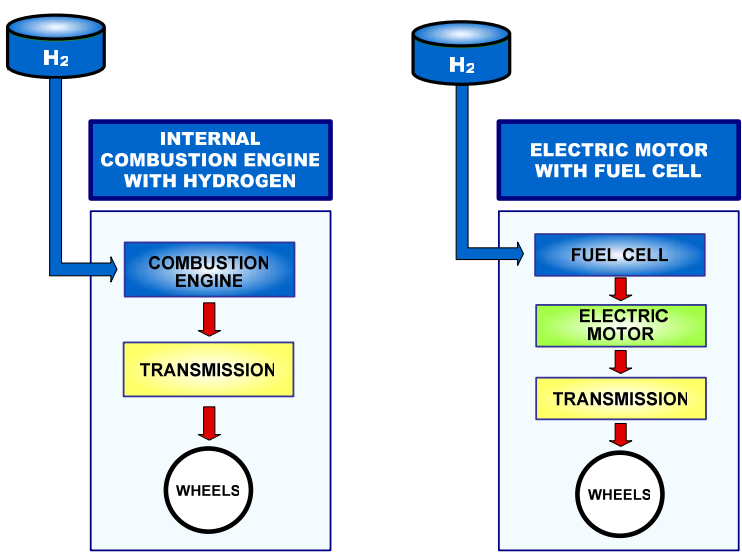

Fig. 1. Options for the use of hydrogen in transport

Considering these two options, a comparative analysis of different performance criteria is exposed, in order to make a choice between the two alternatives. Table I shows the selection criteria, a brief description of them and the weight assigned in order of significance.

Table I. Selection criteria and weightings

\begin{tabular}{|l|l|c|}
\hline \multicolumn{1}{|c|}{ Selection criteria } & \multicolumn{1}{|c|}{ Description } & Weighting \\
\hline $\mathrm{CO}_{2}$ emissions & Amount of $\mathrm{CO}_{z}$ emitted into the atmosphere \\
\hline \hline Respect for the environment & Use of materials harmful to people animals or nature & $\mathbf{1 0}$ \\
\hline \hline Efficiency & Distance that the bus could go with a fixed amount of energy & $\mathbf{8}$ \\
\hline \hline Reliability & Probability that the system works correctly & $\mathbf{8}$ \\
\hline \hline Autonomy & Distance that the bus could go with a single refueling & $\mathbf{6}$ \\
\hline \hline Useful life & Operational lifetime of the system & $\mathbf{5}$ \\
\hline \hline Cost & Capital necessary for the execution of the proposed syster & $\mathbf{4}$ \\
\hline
\end{tabular}

Table II shows the numerical value assigned to each of the two technologies, in different criteria, depending on the advantages and disadvantages that affect each alternative.

Table II. Criteria evaluation

\begin{tabular}{|l|l|l|}
\hline \multicolumn{1}{|c|}{ Selection criteria } & $\mathrm{H}_{2}$ Combustion & Fuel Cells \\
\hline $\mathrm{CO}_{2}$ emissions & $\mathbf{8}$ & $\mathbf{1 0}$ \\
\hline \hline Respect for the environment & $\mathbf{8}$ & $\mathbf{9}$ \\
\hline \hline Efficiency & $\mathbf{5}$ & $\mathbf{8}$ \\
\hline \hline Reliability & $\mathbf{7}$ & $\mathbf{7}$ \\
\hline \hline Autonomy & $\mathbf{6}$ & $\mathbf{7}$ \\
\hline Useful life & $\mathbf{7}$ & $\mathbf{7}$ \\
\hline \hline Cost & $\mathbf{7}$ & $\mathbf{2}$ \\
\hline
\end{tabular}

Finally, Table III details the obtained results for selecting the most appropriate alternative for the bus propulsion system.

Table III. Final comparison of alternatives

\begin{tabular}{|c|c|c|c|}
\hline Selection criteria & Weighting & $\mathrm{H}_{2}$ Combustion & Fuel Cells \\
\hline $\mathrm{CO}_{2}$ emissions & 10 & 80 & 100 \\
\hline Respect for the environment & 9 & 72 & 81 \\
\hline Efficiency & 8 & 40 & 64 \\
\hline Reliability & 8 & 56 & 56 \\
\hline Autonomy & 6 & 36 & 42 \\
\hline Useful life & 5 & 35 & 35 \\
\hline Cost & 4 & 28 & 8 \\
\hline TOTAL & & 347 & 386 \\
\hline
\end{tabular}

From the results in Table III, it was observed that the fuel cells technology is most suitable for the extraction of hydrogen's potential energy, considering the parameters of efficiency as well as harmful emissions and noise.

\section{Structure of the fuel cell bus}

Considering standards, properties, advantages and disadvantages of different modes of propulsion in urban public transport, an alternative design of an electric bus is exposed. This bus will work with fuel cells and solar panels.

The fuel cell is the essential device for the electrical generation applied to the electric bus. This fuel cell has to provide the most of the power required by electric drive motors of the bus and auxiliary control and conditioning devices.

Additionally, fuel cells used in transport require some special features, such as: small start-up times, high efficiency, high energy density and a good response to the change in power demand. In this case, the PEM fuel cell is best suited to meet these requirements.

Figure 2 shows the block diagram of the components that constitute the generation system and power management for bus propulsion. The block diagram is made up of the following devices:

1) PEM Fuel Cell.

2) Monocrystalline silicon PV modules.

3) Lithium ion batteries.

4) Ultracapacitors.

5) Tank of hydrogen.

6) Electrolyzer.

7) Charge controller for battery.

8) Maximum Power Point Tracker (MPPT).

9) $\mathrm{DC} / \mathrm{DC}$ converters.

10) DC/AC Inverter.

11)Electrical Motors.

12)Auxiliary electrical loads.

13)Air and hydrogen compressors.

14)Hydrogen pipes, valves, seals and gaskets.

15)Electrical wires. 


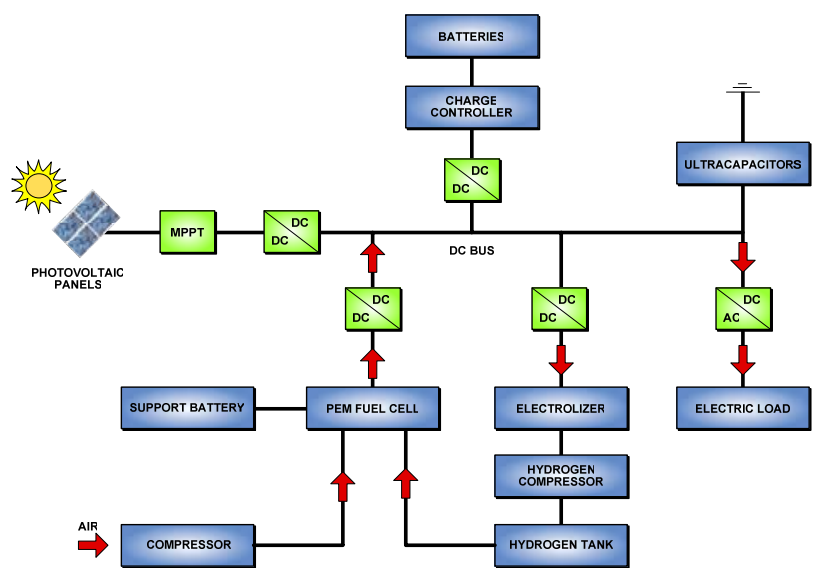

Fig. 2. Block diagram of the electrical bus

The different devices are interconnected through a DC bus. This DC bus allows adapting and exchanging energy between different devices. Below, the allowed energy flows in the system are listed:

- Fuel cell feeds mainly the electric load, i.e. the traction electric motors and auxiliary equipment.

- Ultracapacitors are responsible for supplying power during peaks of the bus start-up and storing energy recovered from regenerative braking.

- Battery will support the system in case of high demand, high load bus and uphill stretch.

- These batteries can be recharged externally when the bus is idle, thereby reducing the consumption of hydrogen, or by the fuel cell when the bus does not demand high load.

- PV modules feed to electric loads and batteries.

- Electrolyzer will be powered by photovoltaic modules if the bus is stopped, in case that batteries and ultracapacitors are charged.

Figure 3 shows the layout of the most relevant equipment in the structure of fuel cell bus. The Mercedes Citaro has been chosen as bus platform, with standard $12 \mathrm{~m}$ length, $2.55 \mathrm{~m}$ width and $3.67 \mathrm{~m}$ height. The bus has capacity for 30 people seated, with a maximum of 70 passengers.

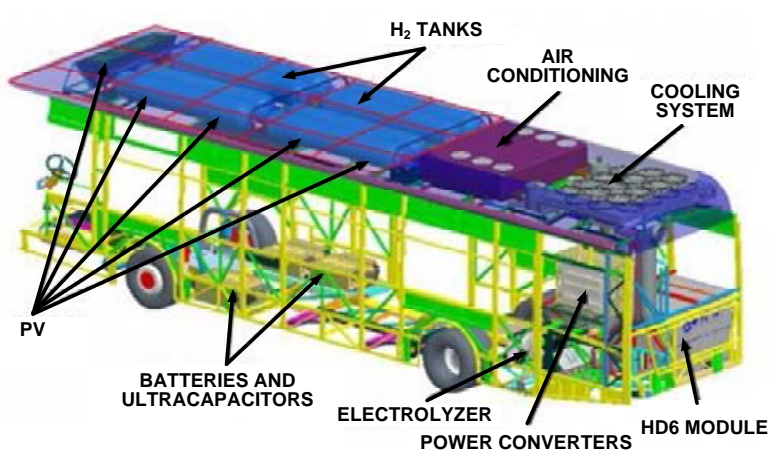

Fig. 3. Bus devices layout

\section{Description of components}

Following, general characteristics of some devices are included.

\section{A. Fuel cell}

The PEM fuel cell used is a Ballard HD6 Velocity ${ }^{\mathrm{TM}}$ that is specifically designed for electric drive buses. Figure 4 shows the access terminals for different products as well as control signals for the mentioned model. Its main characteristics appear in Table IV.

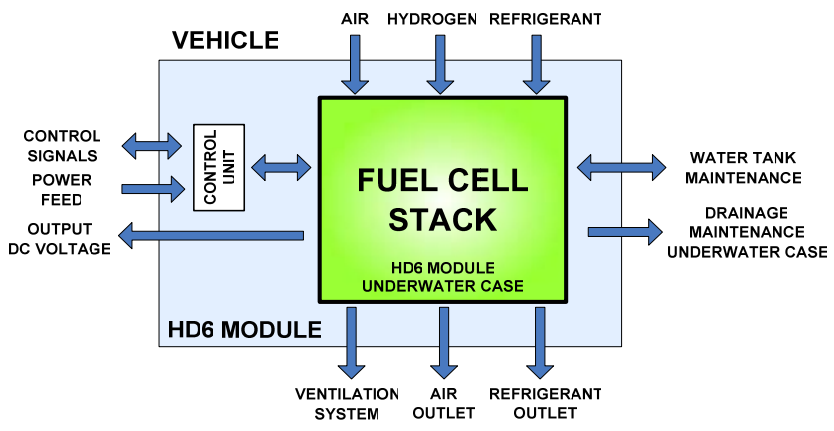

Fig. 4. Velocity FC HD6 access terminal

Table IV. Ballard Velocity HD6 ${ }^{\mathrm{TM}}$ characteristics [7]

\begin{tabular}{|l||l|}
\hline Gross Power & $150 \mathrm{~kW}$ \\
\hline \hline Output DC voltage & $550-800 \mathrm{~V}$ \\
\hline \hline Maximum current & $300 \mathrm{~A}$ \\
\hline \hline Weight (dry) & $\mathbf{| l |} 400 \mathrm{~kg}$ \\
\hline \hline Fuel & Hydrogen (SAE J2719) \\
\hline \hline Oxidant & Air \\
\hline \hline Coolant & $50 / 50$ Pure Ethylene Glycol and water \\
\hline \hline Minimum fuel pressure & 12 bar \\
\hline \hline Nominal air pressure & 1.2 bar \\
\hline \hline Nominal temperature & $63^{\circ} \mathrm{C}$ \\
\hline \hline Control interface & CANbus \\
\hline \hline Enclosure & IP53 \\
\hline
\end{tabular}

The integration of the fuel cell in the system requires knowledge of the characteristic curves that define the behaviour of this device. These curves are made at Beginning Of Life (BOL) of the product.

Figure 5 shows the polarization curve of the HD6 TM fuel cell. It can be observed that as the load current is increased, the output voltage is decreased. Therefore is necessary to install a DC/DC converter to make stable the fuel cell output voltage.

Thus, a $150 \mathrm{~kW}$ PEM fuel cell has been chosen, which presents two relevant features in operation. The first one is when the fuel cell is working with no load, this allows to quantify the auxiliary devices power consumption, in this case $10.8 \mathrm{~kW}$. The second relevant feature corresponds to the nominal power of $150 \mathrm{~kW}$.

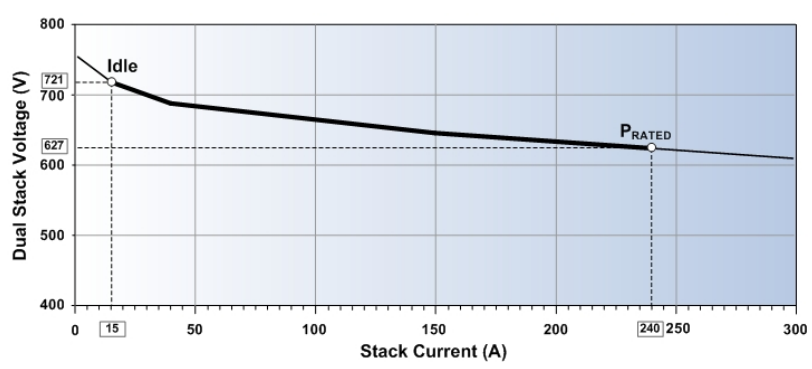

Fig. 5. Ballard FC HD6 polarization curve [8]

Additionally, in the analysis of hydrogen consumption versus fuel cell electric power, it can be observed that 
$150 \mathrm{~kW}$ of rated power corresponds to about $2 \mathrm{~g} / \mathrm{s}$ of hydrogen consumption. Regarding to air consumption at rated power, it is about $130 \mathrm{~g} / \mathrm{s}$ (Figures 6 and 7).

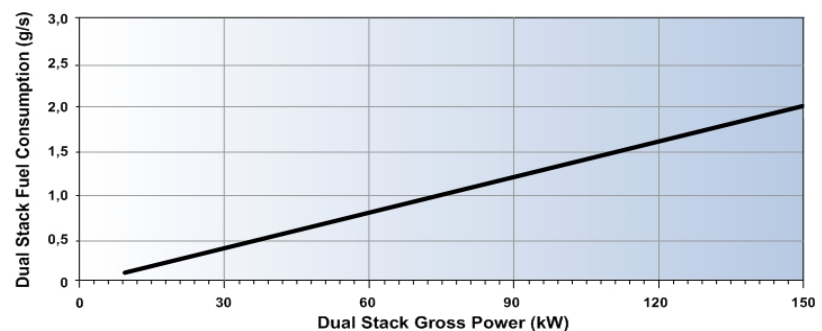

Fig. 6. Ballard FC HD6 hydrogen consumption curve [8]

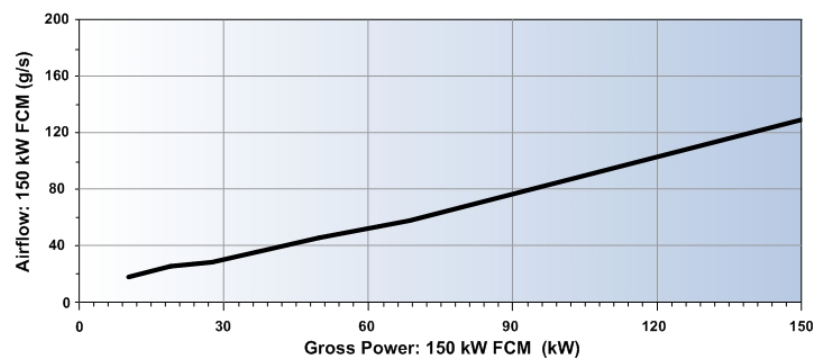

Fig. 7. Ballard FC HD6 air consumption curve [8]

\section{B. PV modules}

In relation to the photovoltaic modules located on the roof of the bus, they take up an area of $20.4 \mathrm{~m}^{2}$. The program PVGIS has been used to evaluate the energy extracted from these photovoltaic modules, in a year, in different locations. The PV module used in the system is a IS-180 model manufactured by Isofoton, whose major characteristics are defined in Table V.

Table. V. Isofoton IS-180 characteristics [9]

\begin{tabular}{|l|c|}
\hline Maximum power & $180 \mathrm{~W}$ \\
\hline \hline Open circuit voltage & $45.2 \mathrm{~V}$ \\
\hline \hline Voltage at maximum power & $36.5 \mathrm{~V}$ \\
\hline \hline Short circuit current & $5.3 \mathrm{~A}$ \\
\hline \hline Current at Maxumum power & $4.93 \mathrm{~A}$ \\
\hline \hline Efficiency & $14 \%$ \\
\hline
\end{tabular}

Taking into account the available surface and the used area by each module, 15 modules can be installed, obtaining a peak power of $2.7 \mathrm{~kW}$. Installation is performed in two parallel branches to avoid overcoming of DC bus voltage system, designed to $400 \mathrm{~V}$.

Figure 8 shows the evolution of monthly average electrical production of the PV system, during a year, in the city of Bilbao (Spain).

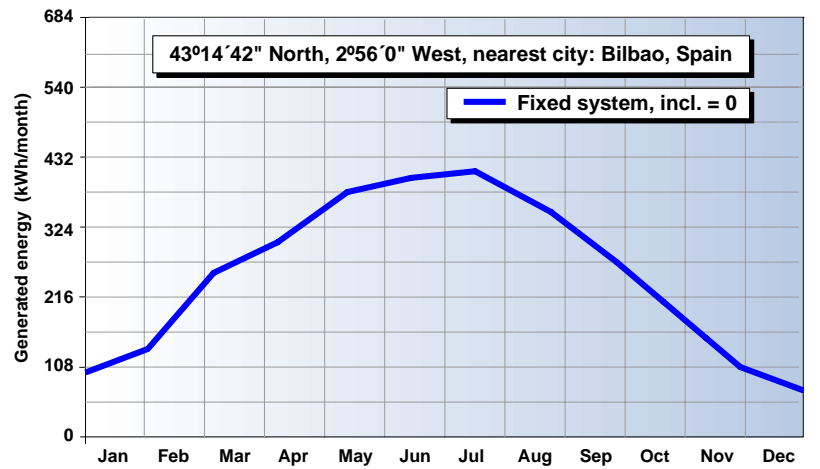

Fig. 9. PV system electrical production
Acquired data for the city of Bilbao indicate that a amount of $3012 \mathrm{kWh}$ can be obtained from the photovoltaic modules. If this energy is used to feed the load or recharge the batteries, could be saved about $161 \mathrm{~kg}$ of hydrogen.

\section{Lithium-ion batteries}

In some situations, for example when the bus drives through a very steep ramp, an extra supply of power to the electric traction system will be needed. Thus, this bus is designed with batteries that can deliver $50 \mathrm{~kW}$ during two hours.

There are commercial lithium-ion batteries that meet the design requirements. The battery used is the model U2712XP U-Charge XP Series, by Valance manufacturer, whose characteristics are shown in Table VI. These batteries have nominal capacity of $138 \mathrm{Ah}$ and nominal voltage of $12.8 \mathrm{~V}$. Besides, they are connected in two parallel branches of 27 devices, in order to not exceeding the rated DC bus voltage and being able to reach the desired capacity.

Table VI. U27-12XP Valence battery characteristics [10]

\begin{tabular}{|c|c|c|}
\hline \multicolumn{2}{|l|}{ Voltage } & $12.8 \mathrm{~V}$ \\
\hline \multicolumn{2}{|c|}{ Rated capacity $\left(23^{\circ} \mathrm{C}\right)$} & $138 \mathrm{Ah}$ \\
\hline \multicolumn{2}{|l|}{ Weight } & $19.5 \mathrm{~kg}$ \\
\hline \multicolumn{2}{|c|}{ Dimensions } & $306 \times 172 \times 225 \mathrm{~mm}$ \\
\hline \multicolumn{2}{|c|}{ Specific energy } & $91 \mathrm{Wh} / \mathrm{kg}$ \\
\hline \multicolumn{2}{|c|}{ Energy density (@23으 } & $148 \mathrm{Wh} / \mathrm{l}$ \\
\hline \multirow{3}{*}{$\begin{array}{l}\text { Standar } \\
\text { discharge } \\
\left(@ 23^{\circ} \mathrm{C}\right)\end{array}$} & Max. Dirent current & $150 \mathrm{~A}$ \\
\hline & Max. 30 sec. pulse & $300 \mathrm{~A}$ \\
\hline & Disconnexion voltage & $10 \mathrm{~V}$ \\
\hline \multirow{4}{*}{$\begin{array}{l}\text { Standar } \\
\text { charge } \\
\left(@ 23^{\circ} \mathrm{C}\right)\end{array}$} & Charge voltage & $14.6 \mathrm{~V}$ \\
\hline & No-load voltage & $13.8 \mathrm{~V}$ \\
\hline & Charge current & $70 \mathrm{~A}$ \\
\hline & Charge time & $2.5 \mathrm{~h}$ \\
\hline \multicolumn{2}{|c|}{ Internal resistance } & $5 \mathrm{~m} \Omega$ \\
\hline \multicolumn{2}{|c|}{ Operating temperature } & $-10^{\circ} \mathrm{C}$ to $50^{\circ} \mathrm{C}$ \\
\hline
\end{tabular}

Additionally in the choice of battery, the discharge characteristic as a function of the discharge capacity (C-rate) has to be considered. This feature provides information on battery voltage according to the percentage of energy stored (Figure 10).

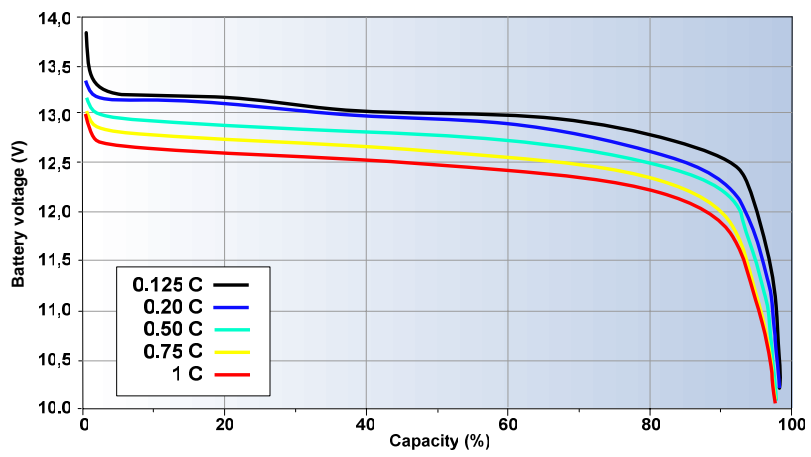

Fig. 10. Discharge performance of U27-12XP battery

Finally, these batteries must be controlled and monitored to prevent overheating. This way, their useful life can be 
increased. It must be keep in mind that these batteries should not be charged or discharged over 1C, as it may cause overheating in the batteries. The unit responsible for carrying out this task is the charge controller.

There is a charge controller specifically designed for these batteries. It's a XP-HV U-BMS (Battery Management System - High Voltage) charge controller, from the same manufacturer as batteries. This charge controller manages the temperature, voltage, current and charging status of each battery module.

\section{Ultracapacitors}

Ultracapacitors have the aim to stabilize the DC bus voltage, supply peak power demand in the electric motor start-up and store energy recovered from braking. The selected ultracapacitor is from Maxwell manufacturer, namely model BMOD0063 P125 B14. Its most important features are shown in Table VII.

Table VII. BMOD0063 P125 ultracapacitor specifications [13]

\begin{tabular}{|l|l|}
\hline Rated capacity & $63 \mathrm{~F}$ \\
\hline \hline Capacity tolerance & $0 \%$ to $+20 \%$ \\
\hline \hline Rated voltage & $125 \mathrm{~V}$ \\
\hline \hline Maximum operating voltage & $130 \mathrm{~V}$ \\
\hline \hline Internal series resistance & $18 \mathrm{~m} \Omega$ \\
\hline \hline Operating temperature & $-40^{\circ} \mathrm{C}$ to $65^{\circ} \mathrm{C}$ \\
\hline \hline Max. Ambient operating temperature & $50^{\circ} \mathrm{C}$ \\
\hline \hline Energy density & $1.75 \mathrm{~kW} / \mathrm{kg}$ \\
\hline \hline Cycles $125 \mathrm{~V}$ to $62.5 \mathrm{~V}$ & $1,000,000$ \\
\hline \hline Lifetime & $100,000 \mathrm{~h}$ \\
\hline \hline Maximum direct current & $150 \mathrm{~A}$ \\
\hline \hline Maximum peak current in $1 \mathrm{sec}$. & $750 \mathrm{~A}$ \\
\hline Dimensions & $762 \times 425 \times 265 \mathrm{~mm}$ \\
\hline \hline Weight & $59.5 \mathrm{~kg}$ \\
\hline
\end{tabular}

This module is specifically designed for heavy transport vehicles such as buses. This is a set of ultracapacitors with a total capacity of $63 \mathrm{~F}$ and $125 \mathrm{~V}$ nominal voltage. As the DC bus has a voltage of $400 \mathrm{~V}, 4$ modules of ultracapacitors in series must be install to overcome the DC bus voltage. The capacity of all the ultracapacitor modules, connected in series, is 63/4 $=15.75 \mathrm{~F}$.

\section{E. Tank of hydrogen}

In relation with hydrogen storage, a commercial tank from Dynetek Industries, specifically the ZM180 model, has been selected. The characteristics of the hydrogen tank are summarized in Table VIII. Considering the data obtained in the CUTE project [3], it is estimated that using 10 tanks, of $4.26 \mathrm{~kg}$ of hydrogen each of those tanks, a maximum autonomy of $400 \mathrm{~km}$ can be obtained.

Table VIII. ZM180 cylinder specifications [11]

\begin{tabular}{|l|c|}
\hline Capacity $\mathrm{H}_{\mathbf{2}}$ & $\mathbf{4 . 2 6} \mathbf{~ k g}$ \\
\hline \hline Diameter & $\mathbf{6 0 2} \mathbf{~ m m}$ \\
\hline \hline Length & $972 \mathrm{~mm}$ \\
\hline \hline Weight & $93 \mathbf{~ k g}$ \\
\hline
\end{tabular}

Regarding the proposed inverter for the bus design, it has to convert the $400 \mathrm{~V}$ DC bus voltage to 380 Vrms threephase AC voltage.

\section{H. Electrical motor}

In relation to the electric motors for bus traction, threephase synchronous motors with permanent magnets have been selected. These motors are $30 \%$ smaller and 10 to 15\% more efficient than the equivalent induction motor. Figure 11 shows the cross section of a permanent magnet synchronous motor and Table $\mathrm{X}$ summarizes the most relevant characteristics of these motors.

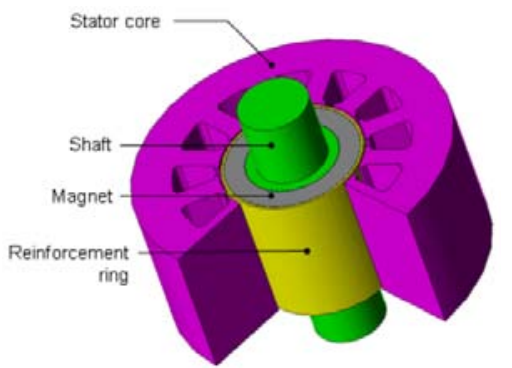

Fig. 11. Permanent magnet synchronous motor 
Table X. Main characteristics of permanent magnet electrical motor

\begin{tabular}{|l|c|c|c|c|c|c|} 
& Power $(\mathrm{kW})$ & Speed $(\mathrm{rpm})$ & Torque $(\mathrm{Nm})$ & Current (A) & Voltage (V) \\
\hline Rear electric engine & 90 & 450 & 1900 & 225 & 400 \\
\hline \hline Front electric engine & 40 & 450 & 850 & 100 & 400 \\
\hline
\end{tabular}

For the implementation on the bus 3 electric motors are used. One will be positioned transversely at the rear axle of the bus, while the other two will be on the front wheels. The distribution of power is $40 \mathrm{~kW}$ for each front wheel and $90 \mathrm{~kW}$ for the rear axle.

\section{Conclusions}

In the environment of clean urban transport, there are numerous proposals for analysis and research in different projects such, as CUTE, ECTOS, STEP, HyFLEET: CUTE, etc. In this context, this paper describes the analysis and design of the structure corresponding to an electric bus.

Currently, fuel cell buses have similar performance features to the internal combustion buses and even higher [3]. The main handicap of hydrogen buses is cost and lack of infrastructure for hydrogen generation and distribution.

The most expensive component of the system is the fuel cell, which represents around one third of the total value of the electric bus. However, the trend in the price of $\mathrm{kWh}$ of fuel cell is reduced each year, while the performance and efficiency of the same increases. In relation with this aspect, Figure 12 shows the modelled cost of an $80 \mathrm{kWnet} \mathrm{PEM} \mathrm{fuel} \mathrm{cell} \mathrm{system} \mathrm{based} \mathrm{on}$ projection to high-volume manufacturing (500,000 units/year). Cost status is based on dollars in the year of the analysis [14].

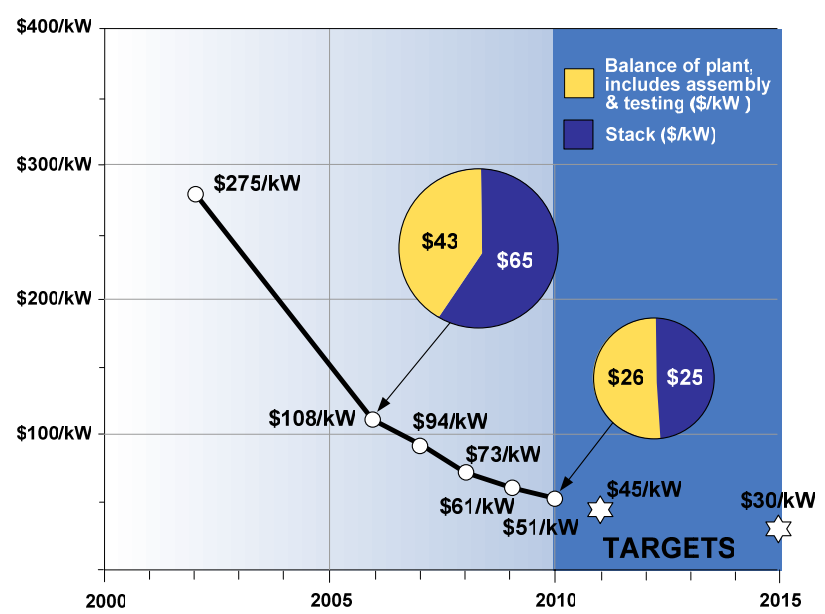

Fig. 12. Modelled cost of an $80 \mathrm{kWnet} \mathrm{PEM} \mathrm{fuel} \mathrm{cell} \mathrm{system}$
Another aspect to consider is the life of the components of the bus. Manufacturer of the HD6 ${ }^{\mathrm{TM}}$ fuel cell provides a guarantee of 12,000 hours or five years, doubling the warranty time of the previous fuel cell MK-902, for buses used in the CUTE project.

The fuel cell technology for electric traction is still not mature and advances in this technology are still going on. Therefore, the use of fuel cells with electrical support devices, such as batteries, can be considered a reliable, efficient and environmentally friendly replacement of fossil fuel-powered buses.

\section{Acknowledgement}

The work presented in this paper has been supported by the Basque Government (Ref. IT532-10) and by the Regional Council of Guipuzcoa.

\section{References}

[1] S.J. Andreasen', L. Ashworth, I. Natanael, M. Remón, S.K Kær "Directly connected series coupled HTPEM fuel cell stacks to a Li-ion battery DC bus for a fuel cell electrical vehicle" International Journal of Hydrogen Energy, Vol.33, pp. 7137-7145, 2008.

[2] L. Xiangjun, X. Liangfei, H. Jianfeng, L. Xinfan, L. Jianqiu, O. Minggao, "Power management strategy for vehicular-applied hybrid fuel cell/battery power system”, Journal of Power Sources, Vol.191, pp.542-549, 2009.

[3] Clean Urban Transport for Europe. Project No.NNE52000-00113. Deliverable No.8. Final Report, 2006.

[4] 2003/30/EC Directive of the European Parliament and the Council of 8 May 2003 on the promotion of the use of biofuels or other renewable fuels for transport.

[5] F. Hernández, C. Rodríguez, J.L. Hernández, "Critical analysis on hydrogen as an alternative to fossil fuels and biofuels for vehicles in Europe”, Renewable and Sustainable Energy Reviews, Vol.14, pp. 772-780, 2010.

[6] J.I. San Martin, I. Zamora, J.J. San Martin, V. Aperribay, E. Torres, P. Eguia, "Influence of the rated power in the performance of different proton exchange membrane (PEM) fuel cells”, Energy, Vo.35, pp.1898-1907, 2010.

[7] http://www.ballard.com/files/pdf/Spec_Sheets/FCvelocityHD6_SPC5101744-

0G.pdfhttp://www.ballard.com/files/pdf/Spec_Sheets/FCve locity-HD6_SPC5101744-0G.pdf

[8] Ballard HD6 ${ }^{\mathrm{TM}}$ Fuel Cell Performance Curves

[9] IS_160-180 specification sheets

[10] http://www.valence.com/sites/default/files/images/UCharge\%20XP\%20datasheet\%20Oct\%202010.pdf

[11] http://www.dynetek.com/pdf/350_Bar_Specifications.pdf

[12] http://www.cres.gr/kape/publications/papers/dimosieyseis/ ydrogen/a\%20review\%20on\%20water\%20electrolysis.pdf

[13] http://www.maxwell.com/docs/datasheet_BMOD0063_10 14696.pdf

[14] http://www.hydrogen.energy.gov/pdfs/10004_fuel_cell_co st.pdf 